\title{
Understanding college students' e-loyalty to online practicum courses in hospitality programmes during Covid-19
}

\section{Yoanita Alexandra}

Universitas Multimedia Nusantara, Indonesia

\section{Septi Fahmi Choirisa}

Universitas Multimedia Nusantara, Indonesia

\section{Abstract}

This study aims to examine the students' loyalty to an online practicum course for hospitality education during the Covid-19 pandemic in Indonesia. Premised on the Technology Acceptance Model (TAM), we adopted a revised model consisting of Information System Success Model and Expectancy Confirmation Theory (ECT) to ascertain the students' perceptions of the usefulness of the programme and their levels of satisfaction with, and eloyalty to, the programme. This study utilised an online survey to obtain data from 309 participants. The partial least squares structural equation modelling method was employed in the study. The findings show that students' perceptions of the usefulness of online learning were significantly influenced by information quality, system quality, and system interactions which relate to satisfaction. Preliminary research provides insight for stakeholders such as vocational institutions, teachers, and practitioners of education to gain a better understanding of factors that contribute to hospitality students' continued intentional use of online courses.

Keywords: e-learning; practicum courses; hospitality students; pandemic; Covid-19; student satisfaction; e-loyalty.

\section{Introduction}

The Covid-19 outbreak, which began in late 2019, has changed world education systems, including in Indonesia. Social restriction policies have led to students studying from home 
using online learning platforms, replacing traditional face-to-face learning. Changing the learning method from conventional education to online learning is not easy; it requires proper and qualified information technology infrastructure support (Giatman, Siswat and Basri, 2020). Anecdotal evidence further suggests that some lecturers have faced technical and practical difficulties which have served to limit the pedagogical preparedness needed to provide meaningful online learning experiences (Rapanta et al., 2020). These challenges may reduce students' motivation and learning effectiveness and also affect their overall satisfaction (Rajabalee and Santally, 2020).

Hospitality programmes usually include practical skills, business knowledge, and soft skills a combination of skills necessary for graduates intending to work in the hospitality industries (Christou and Chatzigeorgiou, 2019). However, the lack of practical application of theory will leave the students without an active learning environment, which is crucial for shaping them into the skilled workforce needed by industries (Robinson, Breakey and Ruhanen, 2015). This learning experience is significant to the students since their levels of satisfaction could affect their desire to continue with the programme (Rajabalee and Santally, 2020). Advances in technology have made possible the development of online learning platforms as learning tools in hospitality education, especially in a pandemic situation. This study sought to examine students' perception, satisfaction, and e-loyalty of online learning usage in practicum courses.

\section{Literature review}

This study was based on the Technology Acceptance Model (TAM). Because of the context of the study, the framework includes external variables and constructs adapted from Expectancy Confirmation Theory (ECT) and Information System (IS) success models which have been applied in previous research conducted by Sung Mi Song (2010).

TAM (Davis, 1989) is often used to explain and predict human behaviour in relation to different computer technologies. TAM has been widely adopted as the main theoretical framework to examine factors which influence the user acceptance of targeted technology, computer systems, or online platforms in a broad range of contexts. The four constructs of 
TAM are perceived ease of use, perceived usefulness, attitude towards use, and behavioural intention (Song and Kong, 2017). Davis identified two central themes of TAM, namely perceived usefulness and perceived ease of use. Perceived usefulness is known as 'the degree to which the person believes that using the particular system would enhance her/his job performance', while perceived ease of use refers to 'the degree to which the person believes that using the particular system would be free of effort' (Davis, 1989, pp.319-340). The attitude itself affects the behavioural intention to use a particular technology, which predicts the actual system use (Jimenez et al., 2020). Satisfaction is a prime indicator of behavioural intention. Students' satisfaction leads to the students' decision to use e-learning and reflects students' e-loyalty (Song, 2010).

On the other hand, Expectation Confirmation Theory (ECT) is widely used to explain postadoption behaviour (Bhattacherjee, 2001). According to the theory, confirmation happens when the perceived performance meets expectations. If there is a difference between them, disconfirmation exists, which affects levels of satisfaction (Oliver, 1980). ECT is often used to predict and explain consumers' satisfaction, including the acceptance of information systems context (Bhattacherjee, 2001; Khalifa and Liu, 2002; Huh and Uysal, 2004).

Furthermore, DeLone and McLean (2003) proposed a model used as a framework for measuring the performance of an information system. Researchers have used the DeLone and McLean Information System (D\&M IS) performance model as a theoretical basis for evaluating e-learning systems and facilities' efficiency from both a consumer and organisational perspective (Chiu et al., 2005; Roca, Chiu and Martínez, 2006; Wang, Wang and Shee, 2007). Most of these studies used the three dimensions of IS quality (information quality, service quality, and system quality) as independent variables and satisfaction as a dependent variable to assess students' satisfaction with e-learning services. For this study, the researcher used four dimensions that suggested perceived usefulness: instructor interaction, service interaction, information quality, and system quality (Song, 2010). 


\section{Instructor interaction}

According to Ghazal et al. (2018), instructors' interactions are essential to students' usage and acceptance of e-learning systems (Al-Busaidi and Al-Shihi, 2010). Instructors should continuously improve themselves to keep updated with the recent pedagogical and technological tools in e-learning and should efficiently prepare e-learning teaching materials (Mtebe and Raisamo, 2014). Moreover, previous literature indicates that positive relationships existed between instructor interaction and perceived usefulness (Lee, Yoon and Lee, 2009).

\section{Service interaction}

E-learning service interaction was positively related to student satisfaction, and in turn, satisfaction affects e-learning student loyalty (Pham et al., 2019). E-learners interactivity is a critical success factor in virtual learning environments because teaching and learning processes are mediated by digital technologies (Rodríguez-Ardura and Meseguer-Artola, 2016). Further study showed that students who learned through e-learning perceive interaction as an effective means of learning; they prefer to interact online (Su et al., 2005).

\section{Information quality}

Information quality refers to the quality of information given on a website. Its measurement includes accuracy, completeness, currency, efficiency, relevance, scope, and timeliness of information (Cheng, 2012). Further, Miyazoe and Anderson (2010) showed that students in an online class saw information as their priority, while students learning in a face-to-face class focused on student-instructor interaction. Previous research also found a positive relationship between information quality and the perceived usefulness of e-learning systems (Salloum et al., 2019).

\section{System quality}

The way that system characteristics affect users' perspectives on using an e-learning system is determined by system quality (Alia, 2016). Research indicates that system quality plays a crucial role in students adopting and using an e-learning system (Salloum et al., 2019). It has 
also been shown that system quality positively affects the perceived usefulness of e-learning (Fathema, Shannon and Ross, 2015; Jaber, 2016; Mahmodi, 2017).

Using the four dimensions of perceived usefulness outlined above, this study proposes the following hypotheses:

$\mathrm{H1}$ : Instructor interaction positively affects student perceived usefulness.

H2: Service interaction positively affects student perceived usefulness.

H3: Information quality positively affects student perceived usefulness.

H4: System quality positively affects student perceived usefulness.

\section{Satisfaction}

Satisfaction refers to the user's acceptance of a system and the level of comfort in its use (Amsal et al., 2020). It refers to perceived usefulness which is informed by users' decisions to accept and adopt an e-learning platform. Moreover, the e-learning system can only be accepted by the students when they perceive that using it will improve their learning performance (Rizun and Strzelecki, 2020). A study conducted by Amsal et al. (2020) proves a positive correlation between perceived usefulness and satisfaction. Junjie (2017) also demonstrates a significant effect of perceived usefulness on satisfaction in the context of a massive open online course (MOOC). Therefore, this study proposes the following hypotheses:

H5: Perceived usefulness positively affects student satisfaction.

\section{E-loyalty}

Previous studies have found that satisfaction with e-learning systems leads to students' continued intentional use of the system (Cheng, 2020; Garg and Sharma, 2020). The current study hypothesises that a key determinant of student e-loyalty is online courses' continuance intention which is reflected by students' satisfaction (Song, 2010). Therefore, this study proposes the following hypothesis: 
H6: Student satisfaction positively affects student e-loyalty.

\section{Research methods}

The methodology used to conduct quantitative research utilised a survey method to collect data by distributing online questionnaires through email in the second and third quarter of 2020. The survey was sent to the 309 hospitality students in Indonesia, with $100 \%$ response rate, who participated in online learning practicum courses during the current pandemic. The questionnaire consists of 55 questions: 9 questions about demographic factors and 46 variable questions using a Likert scale with 5 points of plate: 1 (strongly disagree) to scale 5 (strongly agree). This study analysed 309 questionnaires using Structural Equation Modelling (SEM).

\section{Figure 1. Research Model.}

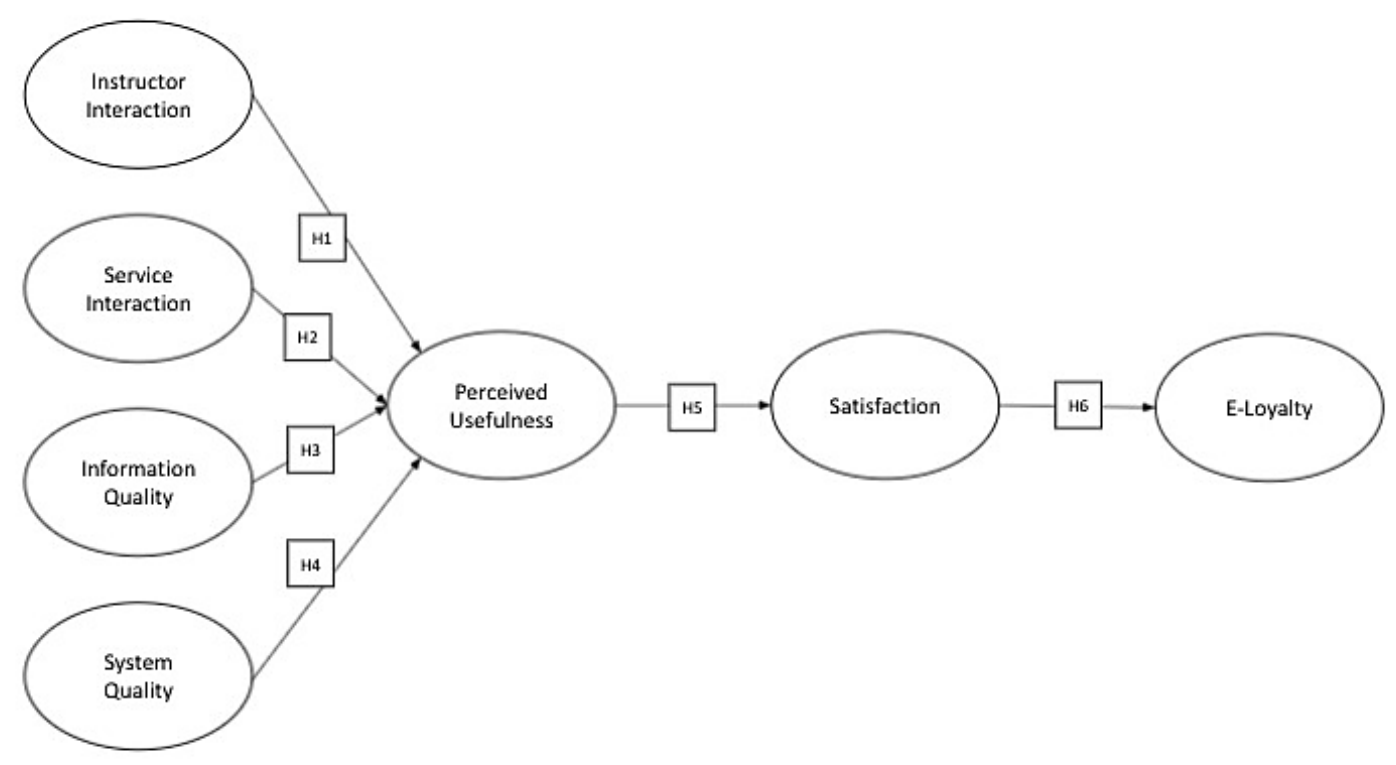


The questionnaire was developed using the seven constructs of the research model: instructor interaction, service interaction, information quality, system quality, perceived usefulness, satisfaction, and e-loyalty.

The questionnaire of perceived usefulness was adapted from Roca et al. (2006). The satisfaction questions were adapted from Keaveney and Young (1997) and the questions of loyalty were adopted from Eggert and Ulaga (2002) and Hennig-Thurau et al. (2001). In order to measure the variable questions, indicators were tested with outer loading values. The standardised outer loadings were used to determine individual item reliability (Roldán and Sánchez-Franco, 2012). The manifest variable should meet a loading of 0.707 or more to be accepted as a constituent of a construct (Carmines and Zeller, 1979; Roldán and SánchezFranco, 2012). Table 1 (Appendix 1) shows that the measurement of each indicator has an excellent consonant to meet the minimum requirements of outer loadings. The strong indicators lead to a better fit in covariance SEM analysis (Roldán and Sánchez-Franco, 2012).

\section{Results and analysis}

The sample comprises $25 \%$ male, $5 \%$ unidentified, and $70 \%$ female respondents. Most respondents are from Java Island, with 73\%, and the rest of the respondents spread across every island in Indonesia. The respondents are college students from different education years and semesters. Most of them (22\%) are in the fourth semester (second year of study). As for experiences, $83 \%$ currently have one-five online courses. $100 \%$ of the respondents are full-time students. Details of respondents' profiles are provided in Table 2 (see Appendix 2).

According to Urbach and Ahlemann (2010) and Hair et al. (2016), PLS-SEM can be used to examine complex structural equation models that consist of several constructs. The measurement data from the indicator or manifest variables are used to input the statistical analysis, proving the relationship among latent variables (Williams, Vandenberg and Edwards, 2009). This research has a reflective model that fits the analysis approach, carried out with reference to reliability and validity attributes (Roldán and Sánchez-Franco, 2012). 
According to Chin (2010) and Hair et al. (2016), PLS is the appropriate option for any researchers who need to use latent variable scores in the predictive relationship of subsequent analysis. This research used the variance-based approach Partial Least Square with Smart PLS 3.0 to conduct the two-step analytical procedure (Anderson and Gerbing, 1988). The first step of measurement model analysis assesses reliability, convergent validity, and discriminant validity. After that, this study assesses the structural model to test its research hypotheses (Rizkalla and Setiadi, 2020).

The three conditions proposed by Fornell and Larcker (1981) were used to determine the convergent validity of the measurement items in this study: (a) the average variance extracted (AVE), (b) item reliability of each measurement, and (c) the composite reliability of each construct. In this process, convergent validity was evaluated by assessing the outer loadings of each indicator and average variance extracted (AVE) (Fornell and Larcker, 1981). AVE values should be greater than 0.50 . This means that $50 \%$ or more of the indicator variance should be accounted for (Roldán and Sánchez-Franco, 2012). As a result, in Table 3 (Appendix 3 ), all the variables above 0.50 indicate an adequate convergent validity measurement.

The value of Composite Reliability (CR) was assessed to determine Internal Consistency Reliability (Kamis, et al., 2020). CR scores need $>0.7$ to ensure adequate internal consistency (Gefen, Straub and Boudreau, 2000; Hair et al., 2016). As depicted in Table 3 (Appendix 3), all values are above the threshold. Moreover, Cronbach's Alpha $\alpha>0.7$ is also a measure of the reliability of items measuring a construct (Nunnally and Bernstein, 1994). The Cronbach Alpha values ranged from 0.902-0.950, proving the scores were acceptable.

The Discriminant Validity in Table 4 (Appendix 4) compares the AVE square root value with construct correlation value that indicates the highest value in any column or row compared to the highest correlation value of any other construct (Hair et al., 2016). Based on the value analysis, results met the criterion. The values responded to the proposed research question related to the construction research framework's validity (Kamis et al., 2020). 
Subsequently, to execute the correlations among the constructs' values and the indicator standardised data, cross loading analysis was used (Gefen and Straub, 2005). It can also reduce the multi-collinearity between the latent variables by indicating the Average Variance Extracted (AVE) value of each indicator that should be higher than the others (Fornell and Larcker, 1981; Chin, 1998; Vinzi, Trinchera and Amato, 2010). The results are shown in Table 5 (Appendix 5 ). The cross-loading values prove the validity of the construct measurement model.

\section{Figure 2. Structural model (Bootstrap).}

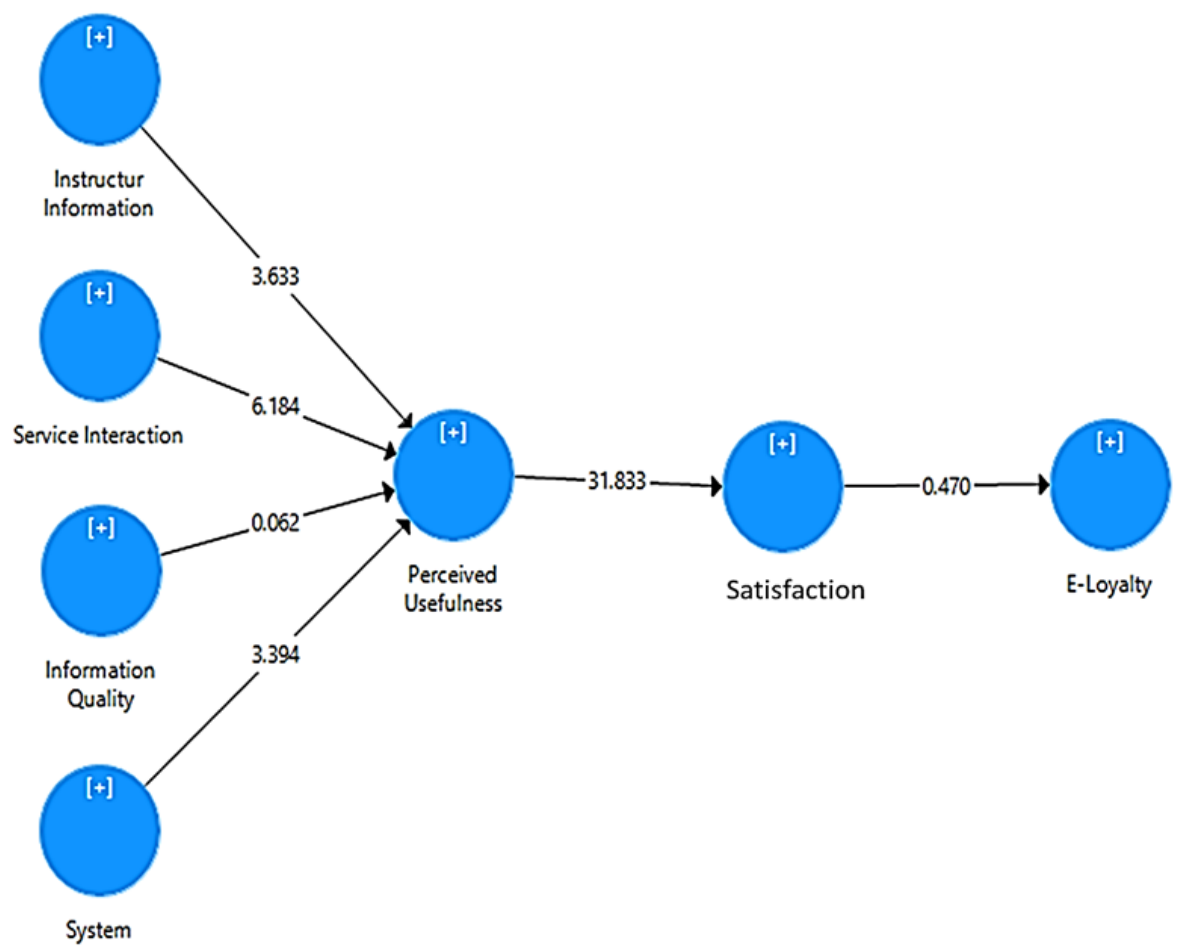

This examination surveys the basic model to test the research hypotheses. The bootstrapping method was utilised with 5000 resamples to examine each of the path coefficients value. (Hair et al., 2016). Based on Table 6 (Appendix 6) and Figure 2, out of the six proposed hypotheses, four were proved to be significant. The first significant variable is functional value $($ Beta $=0.211 ;$ T-value $=3.633 ; p$-value $<0.05)$ which indicates with relation to hypothesis 1 (H1) that instructor interaction had a positive effect on students' perceived usefulness. The second hypothesis value $($ Beta $=0.446 ;$ T-value $=6.184 ; p$-value $<0.01)$ further leads to the 
acceptance of $\mathrm{H} 2$ (service interaction positively affects student perceived usefulness). The fourth hypothesis value (Beta $=0.260 ; \mathrm{T}$-value $=3.394 ; \mathrm{p}$-value $<0.05$ ) is also proven to be significant for system quality influencing the perceived usefulness and the fifth hypothesis value $($ Beta $=0.818 ;$ T-value $=31.833 ; p$-value $<0.05)$ leads to the acceptance of H5 (perceived usefulness positively affects student satisfaction). However, the third hypothesis value $($ Beta $=0.013 ; \mathrm{T}$-value $=0.062 ; \mathrm{p}$-value $>0.05)$ proves that $\mathrm{H} 3$, information quality has no significant effect on student perceived usefulness and the sixth hypothesis value $($ Beta $=-$ $0.037 ;$ T-value $=0.470 ; \mathrm{p}$-value $>0.05$ ) also implies that student satisfaction does not significantly affect e-loyalty.

This study also calculated the $R$ squared $\left(R^{2}\right)$ of the research model to answer the research question. The $\mathrm{R}^{2}$ of perceived usefulness is 0.710 , which indicates that the variation can be accounted for $71 \%$. Meanwhile, the $\mathrm{R}^{2}$ of the satisfaction variable is 0.668 or $66.8 \%$. This indicates that the merged essence of Expectation Disconfirmation Theory, Technology Acceptance Model, and Service Interaction successfully explains the model for online learning satisfaction and e-loyalty.

\section{Discussion}

The path coefficients identified that some of the variables are significantly affected. Table 6 (Appendix 6) shows that perceived usefulness has the strongest effect (0.818) on satisfaction (H5), followed by the effect of service interaction (0.446) on student perceived usefulness (H2). This result aligns with the studies conducted by Amsal et al. (2020) and García Aracil (2009) that show the positive correlation between perceived usefulness and satisfaction. These constructs explain $\mathrm{R}^{2}$ value 0.710 (71\%), which were accounted for by the independent variables of instructor interaction, service interaction, and system quality. System quality (0.260) positively affected the perceived usefulness $(\mathrm{H} 4)$ and to a lesser extent, instructor interaction (0.211) significantly influenced students' perceptions of usefulness $(\mathrm{H} 1)$. This finding aligns with the findings of previous studies (Lee, Yoon and Lee, 2009; Mahmodi, 2017). 
In contrast, information quality is not a positive influence (0.013) on perceived usefulness $(\mathrm{H} 3)$ and satisfaction does not significantly influence student e-loyalty $(\mathrm{H} 6)$. These results are comparable to those of a previous study conducted in Poland, examining the impact of distance learning on students during the pandemic (Rizun and Strzelecki, 2020). Further, service interaction has the strongest effect on perceived usefulness, among the other variables. The indicator of variable measurements (Appendix 1, Table 1) implies the importance of course service delivery and instruction (0.858), engagements $(0.826)$, communication (0.802), and personalisation (0.772) during the learning process.

Moreover, the students' perception of usefulness is a strong indicator (Appendix 1, Table 1) that online learning can improve the student performances (0.861). Secondly, the practicum online course experiences helped the students to develop skills (0.856) and increase learning effectiveness (0.845). These indicators lead to the students' perceptions of the usefulness of conducting practicum distance learning. The students' expectations of online practicum courses show strong satisfaction indicators (0.885). Moreover, it is shown that the students are generally satisfied with the online practicum courses they have taken (0.867). The findings show that the effective learning method emphasised by the Instructor, namely Quality, Service Interaction and System Quality, influenced the students' perceived usefulness which significantly affected satisfaction.

\section{Conclusions and suggestions for further study}

The developed framework has excellent implications for various parties. Although the study focuses on, and is of particular value for, hospitality management programmes that include online practicum course, the study results emphasise the importance of education adapting quickly to new circumstances, by introducing new curricula in response to the students' needs, in this case addressing the issue of limited access to practicum equipment during a pandemic. In particular, at the level of education management, attention should be paid to the ways of learning. An adequate online platform is required to be able to create an interactive learning environment and responsive communication between instructors and students. Alongside this, digital platforms should be designed holistically and include the additional 
features such as learning analytics (Ferguson, 2012). Subsequently, these features used to identify the students' usage of the platform will provide detailed data that could be used to evaluate learning behaviours and could effectively support the learning programme (Song and Kong, 2017).

The research process used in this study is important to future researchers as a source of guidance for developing new instruments for related research. This study also potentially has practical implications for national strategies and decision making. For example, Indonesia's Ministry of Education and Vocational Education Department could formulate an effective strategy for vocational schools or institutions for better online practicum class implementation. Such new initiatives would have the potential to lead education providers to harness digitalisation to develop learning support and identify emerging types of practice (Orr, Weller and Farrow 2018). According to the findings, the most significant factor to influence the students' perceived usefulness is service interaction. Therefore, it is recommended that the educator pays more attention to two-way communications with students and creates an active learning environment in online classes to help students engage during distance learning. Finally, future research and comparative analysis would be valuable in better understanding the broader impact of the Covid-19 pandemic on higher education.

\section{References}

Al-Busaidi, K. and Al-Shihi, H. (2010) 'Instructors' acceptance of learning management systems: a theoretical framework', Communications of The IbIMA, 1-10. https://doi.org/10.5171/2010.862128.

Alia, A. (2016) An investigation of the application of the Technology Acceptance Model (TAM) to evaluate instructors' perspectives on e-learning at Kuwait university. Unpublished PhD thesis. Dublin City University.

Amsal, A. A., Putri, S. L., Rahadi, F. and Fitri, M. E. (2020) 'Perceived satisfaction and perceived usefulness of elearning: the role of interactive learning and social influence', 
Proceedings of the 3rd International Conference on Educational Development and Quality Assurance. 506. Available at: https://www.atlantis-press.com/proceedings/icedqa-20/125952030 (Accessed: 18 January 2021).

Anderson, J. C. and Gerbing, D. W. (1988) 'Structural equation modelling in practice: a review', Psychological Bulletin, 103, pp.411-423. https://doi.org/10.1037/00332909.103.3.411.

Bhattacherjee, A. (2001) 'An empirical analysis of the antecedents of electronic commerce service continuance', Decision Support Systems, 32, pp.201-214. https://doi.org/10.1016/S0167-9236(01)00111-7.

Carmines, E. G. and Zeller, R. A. (1979) Reliability and validity assessment. Beverly Hills: Sage University Paper Series on Quantitative Applications in the Social Sciences. https://dx.doi.org/10.4135/9781412985642.

Cheng, Y.-M. (2012) 'Effects of quality antecedents on e-learning acceptance', Internet Research, 22(3), pp. 361-390. https://doi.org/10.1108/10662241211235699.

Cheng, Y.-M. (2020) 'Students' satisfaction and continuance intention of the cloud-based elearning system: roles of interactivity and course quality factors', Education + Training, 62(9), pp.1037-1059. https://doi.org/10.1108/ET-10-2019-0245.

Chin, W. W. (1998) 'Issues and opinion on structural equation modelling', MIS Quarterly, 22(1), vii-xvi. Available at: http://www.jstor.org/stable/249674 (Accessed: 15 January 2021).

Chin, W. W. (2010) 'How to write up and report pls analyses', in Esposito Vinzi, V., Chin, W., Henseler, J., Wang, H. (eds.) Handbook of Partial Least Squares. Berlin: Springer Handbooks of Computational Statistics. https://doi.org/10.1007/978-3-540-32827-8 29. 
Chiu, C.-M., Hsu, M.-H., Sun, S.-Y., Lin, T.-C. and Sun, P.-C. (2005) 'Usability, quality, value, and e-learning continuance decisions', Computers \& Education, 45, pp.399-416. https://doi.org/10.1016/i.compedu.2004.06.001.

Christou, E. and Chatzigeorgiou, C. (2019) 'Experiential learning through industrial placement in hospitality education: the meat in the sandwich', Journal of Contemporary Education Theory and Research, 3(2), pp.34-41. https://doi.org/10.5281/zenodo.3635961.

Davis, F. D. (1989) 'Perceived usefulness, perceived ease of use, and user acceptance of information technology', MIS Quarterly, 13(3), pp.319-340. https://doi.org/10.2307/249008.

Delone, W. H. and McLean, E. R. (2003). 'The DeLone and McLean model of information systems success: a ten-year update', Journal of Management Information Systems, 19(4), pp.9-30. https://doi.org/10.1080/07421222.2003.11045748.

Eggert, A. and Ulaga, W. (2002) 'Customer perceived value: a substitute for satisfaction in business markets?' Journal of Business and Industrial marketing, 17(2/3), pp.107-118. https://doi.org/10.1108/08858620210419754.

Fathema, N., Shannon, D. M. and Ross, M. (2015) 'Expanding the Technology Acceptance Model (TAM) to examine faculty use of Learning Management Systems (LMSs) in higher education institutions', Journal of Online Learning and Teaching, 11, pp.210233.

Ferguson, R. (2012) 'Learning analytics: drivers, developments and challenges', International Journal of Technology Enhanced Learning, 4(5/6), pp.304-317. https://doi.org/10.1504/IJTEL.2012.051816.

Fornell, C. and Larcker, D. F. (1981) 'Evaluating structural equation models with unobservable variables and measurement error', Journal of Marketing Research, 18, pp.39-50. https://doi.org/10.1177/002224378101800104. 
García-Aracil, A. (2009) 'European graduates' level of satisfaction with higher education', Higher Education, 57(1), pp.1-21. Available at: http://www.jstor.org/stable/40269103 (Accessed: 20 January 2021).

Garg, S. and Sharma, S. (2020) 'User satisfaction and continuance intention for using etraining: a structural equation model', Vision: The Journal of Business Perspective 24(4), pp.441-451. https://doi.org/10.1177/0972262920926827.

Gefen, D. and Straub, D. (2005) 'A practical guide to factorial validity using plsgraph: tutorial and annotated example', Communications of the Association for Information Systems, 16, pp.91-109. https://doi.org/10.17705/1CAIS.01605.

Gefen, D., Straub, D. and Boudreau, M.-C. (2000) 'Structural equation modeling and regression: guidelines for research practice', Communications of the Association for Information Systems, 7(7), pp.1-78. https://doi.org/10.17705/1CAIS.00407.

Ghazal, S., AL-Samarraie, H. and Aldowah, H. (2018) "I am Still learning”: modeling LMS critical success factors for promoting students' experience and satisfaction in a blended learning environment', IEEE Access, (6), pp.77179-77201. https://doi.org/10.1109/ACCESS.2018.2879677.

Giatman, M., Siswati, S. and Basri, I. Y. (2020) 'Online learning quality control in the pandemic Covid-19 Era in Indonesia', Journal of Nonformal Education, 6(2). https://doi.org/10.15294/jne.v6i2.25594.

Hair Jr, J. H., Hult, G. T., Ringle, C. M. and Sarstedt, M. (2016) A primer on partial least squares structural equation modeling (PLS-SEM). London: Sage Publications.

Hennig-Thurau, T., Langer, M. F. and Hansen, U. (2001) 'Modeling and managing student loyalty: an approach based on the concept of relationship quality', Journal of Service Research, 3(4), pp.331-344. https://doi.org/10.1177/109467050134006. 
Huh, J. and Uysal, M. (2004) 'Satisfaction with cultural/heritage sites', Journal of Quality Assurance in Hospitality \& Tourism, 4(3-4), pp.177-194. https://doi.org/10.1300/J162v04n03 12.

Jaber, O. A. (2016) An examination of variables influencing the acceptance and usage of elearning systems in jordanian higher education institutions. Unpublished PhD thesis. Cardiff Metropolitan University.

Jimenez, I. C., García, L. C., Violante, M. G. and Vezzetti, E. (2020) 'Commonly used external TAM variables in virtual reality, e-learning and agriculture applications: a literature review using QFD as organizing framework', Preprints 2020. https://doi.org/10.20944/preprints202010.0023.v1.

Junjie, Z. (2017). 'Exploring the factors affecting learners' continuance intention of MOOCs for online collaborative learning: an extended ECM perspective', Australasian Journal of Educational Technology, 33(5), pp.123-135. https://doi.org/10.14742/ajet.2914.

Kamis, A., Saibon, R. A., Yunus, F. N., Rahim, M. B., Herrera, L. M. and Montenegro, P. Y. (2021) 'The SmartPLS analyzes approach in validity and reliability of graduate marketability instrument', Turkish Journal of Computer and Mathematics Education, 12(3), pp.829-841. https://doi.org/10.17762/turcomat.v12i3.791.

Keaveney, S. and Young, C. (1997) 'The student satisfaction and retention model (SSRM)', Working Paper, University of Colorado at Denver.

Khalifa, M. and Liu, V. (2002) 'Satisfaction with internet-based services: the role of expectations and desires', International Journal of Electronic Commerce, 7(2), pp.3149. https://doi.org/10.1080/10864415.2002.11044267. 
Lee, B.-C., Yoon, J.-O., and Lee, I. (2009) 'Learners' acceptance of e-learning in South Korea: theories and results', Computers \& Education, 53(4), pp.1320-1329. https://doi.org/10.1016/j.compedu.2009.06.014.

Mahmodi, M. (2017) 'The analysis of the factors affecting the acceptance of e-learning in higher education', Interdisciplinary Journal of Virtual Learning in Medical Sciences, 8(1). https://doi.org/10.5812/IJVLMS.11158.

Miyazoe, T. and Anderson, T. (2010) 'Empirical research on learners' perceptions: interaction equivalency theorem in blended learning', The European Journal of Open Distance and E-Learning. Available at: https://files.eric.ed.gov/fulltext/EJ911753.pdf (Accessed: 8 January 2021).

Mtebe, J. S. and Raisamo, R. (2014) 'A model for assessing Learning Management System success in higher education in Sub-Saharan countries', The Electronic Journal of Information Systems in Developing Countries, 61(7), pp.1-17. https://doi.org/10.1002/j.1681-4835.2014.tb00436.x.

Nunnally, J. and Bernstein, I. (1994) Psychometric Theory. 3rd edn. New York: McGraw-Hill.

Oliver, R. L. (1980) 'A cognitive model of the antecedents and consequences of satisfaction decisions', Journal of Marketing Research, 17(4), pp.460-469. https://doi.org/10.1177/002224378001700405.

Orr, D., Weller, M., and Farrow, R. (2018) 'Models for online, open, flexible and technology enhanced higher education across the globe - a comparative analysis'. Oslo, Norway: International Council for Open and Distance Education (ICDE). Available at: https://oofat.oerhub.net/OOFAT/. (Accessed: 5 January 2021)

Pham, L., Limbu, Y. B., Bui, T. K., Nguyen, H. T. and Pham, H. T. (2019) 'Does e-learning service quality influence e-learning student satisfaction and loyalty? Evidence from 
Vietnam', International Journal of Educational Technology in Higher Education, 16. https://doi.org/10.1186/s41239-019-0136-3.

Rajabalee, Y. B. and Santally, M. I. (2020) 'Learner satisfaction, engagement and performances in an online module: implications for institutional e-learning policy', Education and Information Technologies, 26, pp.2623-2656. https://doi.org/10.1007/s10639-020-10375-1.

Rapanta, C., Botturi, L., Goodyear, P., Guàrdia, L. and Koole, M. (2020) 'Online university teaching during and after the Covid-19 crisis: refocusing teacher presence and learning activity', Postdigital Science and Education, 2, pp.923-945. https://doi.org/10.1007/s42438-020-00155-y.

Rizkalla, N. and Setiadi, D. D. (2020) 'Appraising the influence of theory of consumption values on environmentally-friendly product purchase intention in Indonesia'. Management \& Marketing, XVII, pp.7-25. Available at: https://www.mnmk.ro/documents/2020 1/1-7-1-20.pdf (Accessed: 18 January 2021)

Rizun, M. and Strzelecki, A. (2020) 'Students' acceptance of the COVID-19 impact on shifting higher education to distance learning in Poland', Environmental Research and Public Health, 17(18), p.6468. https://doi.org/10.3390/ijerph17186468.

Robinson, R. N., Breakey, N. and Ruhanen, L. (2015) 'Tourism and Hospitality internships: influences on student career aspirations', Current Issues in Tourism, 19(6), pp.513527. https://doi.org/10.1080/13683500.2015.1020772.

Roca, J. C., Chiu, C.-M. and Martínez, F. J. (2006) 'Understanding e-learning continuance intention: an extension of the technology acceptance model', International Journal of Human-Computer Studies, 64(8), pp.683-696. https://doi.org/10.1016/j.ijhcs.2006.01.003. 
Rodríguez-Ardura, I. and Meseguer-Artola, A. (2016) 'E-learning continuance: the impact of interactivity and the mediating role of imagery, presence and flow, Information and Management, 53(4), pp.504-516. https://doi.org/10.1016/j.im.2015.11.005.

Roldán, J. and Sánchez-Franco, M. (2012) 'Variance-based structural equation modeling: guidelines for using partial least squares in information systems research', in M. Mora, O. Gelman, A, Steenkamp, and M. Raisinghani (eds.), Research Methodologies, Innovations and Philosophies, in Software Systems Engineering and Information Systems, pp.193-221. https://doi.org/10.4018/978-1-4666-0179-6.ch010.

Salloum, S. A., Alhamad, A. M., Al-emran, M., Monem, A. A. and Shaalan, K. (2019). 'Exploring students' acceptance of e-learning through the development of a comprehensive Technology Acceptance Model'. IEEE Access, 7, pp.128445-128462. https://doi.org/10.1109/ACCESS.2019.2939467.

Song, S. M. (2010) E-learning: Investigating students' acceptance of online learning in hospitality programs. Graduate Theses and Dissertations, lowa State University.

Song, Y. and Kong, S.-C. (2017) 'Investigating students' acceptance of a statistical learning platform using Technology Acceptance Model', Journal of Educational Computing Research, 55(6). https://doi.org/10.1177/0735633116688320.

Su, B., Bonk, C. J., Magjuka, R. J., Liu, X. and Lee, S.-h. (2005) 'The importance of interaction in web-based education: a program-level case study of online MBA courses', Journal of Interactive Online Learning, 4 pp.1-19. Available at: https://www.ncolr.org/jiol/issues/pdf/4.1.1.pdf (Accessed: 4 January 2021).

Urbach, N. and Ahlemann, F. (2010) 'Structural equation modelling in information systems research using partial least squares', Journal of Information Technology Theory and Application, 11(2), pp.5-40. Available at: https://aisel.aisnet.org/jitta/vol11/iss2/2 (Accessed: 4 January 2021). 
Vinzi, V. E., Trinchera, L., and Amato, S. (2010) PLS path modeling: from foundations to recent developments and open issues for model assessment and improvement. Berlin: Springer Handbooks of Computational Statistics.

Wang, Y.-S., Wang, H.-Y. and Shee, D. Y. (2007) 'Measuring e-learning systems success in an organizational context: scale development and validation', Computers in Human Behavior, 23, pp.1792-1808. https://doi.org/10.1016/j.chb.2005.10.006.

Williams, L. J., Vandenberg, R. J. and Edwards, J. R. (2009) 'Structural equation modeling in management research: a guide for improved analysis', The Academy of Management Annals, 3(1), pp.543-604. https://doi.org/10.1080/19416520903065683.

\section{Appendix}

Appendix 1. Table 1. Measurement and Outer Loadings.

\begin{tabular}{|c|c|c|c|}
\hline Variable & Code & Indicator & Outer Loading \\
\hline \multirow{6}{*}{$\begin{array}{l}\text { Instructor } \\
\text { Interactions }\end{array}$} & II1 & $\begin{array}{l}\text { During the COVID-19 situation, the online instructor was easy } \\
\text { to get in touch with. }\end{array}$ & 0.795 \\
\hline & II2 & $\begin{array}{l}\text { My practicum courses online instructor had a high level of } \\
\text { expertise in the implementation of the online course. }\end{array}$ & 0.794 \\
\hline & II3 & $\begin{array}{l}\text { During the COVID-19 situation, my practicum courses online } \\
\text { instructor gave fast feedback via a variety of methods. }\end{array}$ & 0.842 \\
\hline & 114 & $\begin{array}{l}\text { My practicum courses online instructor supported and } \\
\text { counselled me with regard to my learning processes. }\end{array}$ & 0.850 \\
\hline & 115 & $\begin{array}{l}\text { My practicum courses online instructor frequently offered } \\
\text { opinions to students. }\end{array}$ & 0.844 \\
\hline & 116 & $\begin{array}{l}\text { My practicum courses online instructor frequently asked the } \\
\text { students questions. }\end{array}$ & 0.789 \\
\hline \multirow{4}{*}{$\begin{array}{c}\text { Service } \\
\text { Interaction }\end{array}$} & SI1 & The practicum online hospitality course has a good reputation & 0.839 \\
\hline & $\mathrm{SI} 2$ & $\begin{array}{l}\text { The practicum online hospitality course makes me feel } \\
\text { connected in interactions. }\end{array}$ & 0.826 \\
\hline & $\mathrm{SI} 3$ & $\begin{array}{l}\text { The practicum online hospitality course secure personal } \\
\text { information. }\end{array}$ & 0.783 \\
\hline & $\mathrm{SI} 4$ & $\begin{array}{l}\text { The practicum online hospitality course creates a sense of } \\
\text { personalisation. }\end{array}$ & 0.772 \\
\hline
\end{tabular}



courses in hospitality programmes during Covid-19

\begin{tabular}{|c|c|c|c|}
\hline & SI5 & $\begin{array}{l}\text { The practicum online hospitality course creates a sense of } \\
\text { community. }\end{array}$ & 0.820 \\
\hline & Si6 & $\begin{array}{l}\text { The practicum online hospitality course makes it easy to } \\
\text { communicate my needs with the university. }\end{array}$ & 0.802 \\
\hline & SI7 & $\begin{array}{l}\text { The practicum online hospitality course service and instruction } \\
\text { will be delivered as promised. }\end{array}$ & 0.858 \\
\hline \multirow{7}{*}{$\begin{array}{l}\text { Information } \\
\text { Quality }\end{array}$} & IQ1 & $\begin{array}{l}\text { The online practicum courses hospitality course provides } \\
\text { accurate information. }\end{array}$ & 0.818 \\
\hline & IQ2 & $\begin{array}{l}\text { The online practicum hospitality courses provide good } \\
\text { information and supporting the course goal. }\end{array}$ & 0.870 \\
\hline & IQ3 & $\begin{array}{l}\text { Online practicum hospitality courses provide timely } \\
\text { information. }\end{array}$ & 0.847 \\
\hline & IQ4 & $\begin{array}{l}\text { The online practicum hospitality courses provide relevant } \\
\text { information (enough for me to master the course content) }\end{array}$ & 0.847 \\
\hline & IQ5 & $\begin{array}{l}\text { The online practicum hospitality courses provide easy to } \\
\text { understand information. }\end{array}$ & 0.838 \\
\hline & IQ6 & $\begin{array}{l}\text { The online practicum hospitality courses provide the right level } \\
\text { of detailed information. }\end{array}$ & 0.857 \\
\hline & IQ7 & $\begin{array}{l}\text { The online practicum hospitality courses provide an } \\
\text { appropriate format of information. }\end{array}$ & 0.865 \\
\hline \multirow{8}{*}{$\begin{array}{l}\text { System } \\
\text { Quality }\end{array}$} & SY1 & $\begin{array}{l}\text { My interaction with the site is clear and understandable for } \\
\text { practicum courses. }\end{array}$ & 0.764 \\
\hline & SY2 & I find the site easy to navigate for practicum courses. & 0.776 \\
\hline & SY3 & I find the site easy to use for practicum courses. & 0.816 \\
\hline & SY4 & The site has an attractive appearance for practicum courses. & 0.793 \\
\hline & SY5 & The site has a fast browsing speed for practicum courses. & 0.811 \\
\hline & SY6 & $\begin{array}{l}\text { The design is appropriate for the type of online practicum } \\
\text { courses site. }\end{array}$ & 0.802 \\
\hline & SY7 & $\begin{array}{l}\text { The site conveys a sense of competency for practicum } \\
\text { courses. }\end{array}$ & 0.835 \\
\hline & SY8 & The site creates a positive experience for myself. & 0.744 \\
\hline \multirow{4}{*}{$\begin{array}{l}\text { Perceived } \\
\text { Usefulness }\end{array}$} & PU1 & $\begin{array}{l}\text { I think the experience of the practicum online course in my } \\
\text { major has helped me to develop a clearer idea of my future } \\
\text { career plans. }\end{array}$ & 0.831 \\
\hline & PU2 & $\begin{array}{l}\text { I think the experience of the practicum online course in my } \\
\text { major has helped me to develop my skills in expressing myself } \\
\text { verbally and in writing. }\end{array}$ & 0.811 \\
\hline & PU3 & $\begin{array}{l}\text { The experience of the practicum online course in my major has } \\
\text { helped me develop the skills needed to get a better job. }\end{array}$ & 0.856 \\
\hline & PU4 & $\begin{array}{l}\text { The experience of the practicum online course in my major has } \\
\text { helped me improve the skills I need for my career. }\end{array}$ & 0.847 \\
\hline
\end{tabular}



courses in hospitality programmes during Covid-19

\begin{tabular}{|c|c|c|c|}
\hline & PU5 & $\begin{array}{l}\text { The experience of the practicum online course in my major has } \\
\text { helped me strengthen my basic hospitality practicum skills. }\end{array}$ & 0.836 \\
\hline & PU6 & $\begin{array}{l}\text { The experience of the practicum online course in my major has } \\
\text { helped me increase my overall knowledge of hospitality } \\
\text { operations. }\end{array}$ & 0.843 \\
\hline & PU7 & $\begin{array}{l}\text { Using practicum online learning services can improve my } \\
\text { learning performance. }\end{array}$ & 0.861 \\
\hline & PU8 & $\begin{array}{l}\text { Using practicum courses, online learning services can increase } \\
\text { my learning effectiveness. }\end{array}$ & 0.845 \\
\hline & PU9 & $\begin{array}{l}\text { I find the practicum courses online learning service to be useful } \\
\text { to me. }\end{array}$ & 0.884 \\
\hline \multirow{5}{*}{$\begin{array}{l}\text { Consumer } \\
\text { Satisfaction }\end{array}$} & TFL1 & $\begin{array}{l}\text { My experience with online practicum courses during COVID-19 } \\
\text { situation was better than I expected. }\end{array}$ & 0.856 \\
\hline & TFL2 & $\begin{array}{l}\text { The learning experience in online practicum courses was } \\
\text { better than I expected. }\end{array}$ & 0.870 \\
\hline & TFL3 & $\begin{array}{l}\text { Overall, most of my expectations with the online practicum } \\
\text { courses during the COVID-19 situation were confirmed. }\end{array}$ & 0.885 \\
\hline & TFL4 & $\begin{array}{l}\text { The online practicum program on our campus compares } \\
\text { favorably to other institutions around the country. }\end{array}$ & 0.839 \\
\hline & TFL5 & $\begin{array}{l}\text { I am generally satisfied with the quality of the online practicum } \\
\text { course(s) in our department. }\end{array}$ & 0.867 \\
\hline \multirow{4}{*}{ E-Loyalty } & SL1 & $\begin{array}{l}\text { I am likely to retake an online practicum course from the } \\
\text { current hospitality program. }\end{array}$ & 0.908 \\
\hline & SL2 & $\begin{array}{l}\text { I am likely to take another online practicum course that is } \\
\text { provided by this hospitality program. }\end{array}$ & 0.929 \\
\hline & SL3 & $\begin{array}{l}\text { I will recommend other people to take practicum online } \\
\text { courses from this hospitality program. }\end{array}$ & 0.909 \\
\hline & SL4 & $\begin{array}{l}\text { I will say positive things to other people about the services } \\
\text { provided at this hospitality program. }\end{array}$ & 0.741 \\
\hline
\end{tabular}




\section{Appendix 2. Table 2. Demographics of the Subjects $(\mathrm{N}=309)$.}

\begin{tabular}{llcc}
\hline Variable & Category & Frequencies & Percentage (\%) \\
\hline Gender & Femsle & 218 & $70 \%$ \\
& Male & 76 & $25 \%$ \\
& Unidentified & 15 & $5 \%$
\end{tabular}

Island

Java Island

$226 \quad 73 \%$

Kalimantan Island

Kepulauan Sunda Kecil (NTB, NTT, Bali)

$17 \quad 6 \%$

Sulswesi Island

Sumatra Island

$25 \quad 8 \%$

$9 \quad 3 \%$

Clas

Semester 1

Semester 2

Semester 3

Semester 4

Semester 5

Semester 6

Semester 7

Semester 8

$>$ Semester 8

$32 \quad 10 \%$

Semester 6
Semester 7
Semester 8
> Semester 8

$26 \quad 9 \%$

Courses $\quad 1-5$ class

5-10 class

More than 10 class

$5018 \%$

$31 \quad 10 \%$

$68 \quad 22 \%$

$50 \quad 18 \%$

$45 \quad 15 \%$

$7 \quad 2 \%$

$3 \%$

$227 \%$

$\begin{array}{ll}\text { Courses } & 1-5 \text { class } \\ & 5-10 \text { class } \\ & \text { More than } 10 \text { class }\end{array}$

$257 \quad 83 \%$

$32 \quad 10 \%$

Enrollment

status

Full-time Student

309

$100 \%$

Appendix 3. Table 3. Convergent Validity and Reliability.

\begin{tabular}{|c|c|c|c|c|}
\hline & $\begin{array}{c}\text { No.of } \\
\text { Indicators }\end{array}$ & $\begin{array}{c}\text { Cronbach's } \\
\text { Alpha }\end{array}$ & CR & AVE \\
\hline Instructur Information & 6 & 0.902 & 0.925 & 0.672 \\
\hline Service Interaction & 7 & 0.915 & 0.932 & 0.664 \\
\hline
\end{tabular}




\begin{tabular}{|c|c|c|c|c|}
\hline Information Quality & 7 & 0.935 & 0.948 & 0.721 \\
\hline System Quality & 8 & 0.915 & 0.931 & 0.629 \\
\hline Perceived Usefulness & 9 & 0.950 & 0.958 & 0.716 \\
\hline Satisfaction & 5 & 0.915 & 0.936 & 0.746 \\
\hline E-Loyalty & 4 & 0.903 & 0.928 & 0.765 \\
\hline
\end{tabular}

Appendix 4, Table 4. Discriminant Validity.

Fornell-Larcker Criterion

\begin{tabular}{|l|l|l|l|l|l|l|l|}
\hline Variables & $\begin{array}{l}\text { Satisfa } \\
\text { ction }\end{array}$ & $\begin{array}{l}\mathrm{E}- \\
\text { Loyalt } \\
\mathbf{y}\end{array}$ & $\begin{array}{l}\text { Informa } \\
\text { tion } \\
\text { Quality }\end{array}$ & $\begin{array}{l}\text { Instruct } \\
\text { or } \\
\text { Informa } \\
\text { tion }\end{array}$ & $\begin{array}{l}\text { Perceiv } \\
\text { ed } \\
\text { Useful } \\
\text { ness }\end{array}$ & $\begin{array}{l}\text { Service } \\
\text { Interac } \\
\text { tion }\end{array}$ & $\begin{array}{l}\text { Syst } \\
\text { em }\end{array}$ \\
\hline CS & $\mathbf{0 . 8 6 4}$ & & & & & & \\
\hline E-Loyalty & -0.036 & $\mathbf{0 . 8 7 5}$ & & & & & \\
\hline $\begin{array}{l}\text { Information } \\
\text { Quality }\end{array}$ & 0.768 & -0.032 & $\mathbf{0 . 8 4 9}$ & & & & \\
\hline $\begin{array}{l}\text { Instructor } \\
\text { Information }\end{array}$ & 0.755 & -0.038 & 0.741 & $\mathbf{0 . 8 2 0}$ & & & \\
\hline $\begin{array}{l}\text { Perceived } \\
\text { Usefulness }\end{array}$ & 0.817 & 0.018 & 0.726 & 0.714 & $\mathbf{0 . 8 4 6}$ & & \\
\hline $\begin{array}{l}\text { Service } \\
\text { Interaction }\end{array}$ & 0.794 & 0.003 & 0.809 & 0.738 & 0.805 & $\mathbf{0 . 8 1 5}$ & \\
\hline $\begin{array}{l}\text { System } \\
\text { Quality }\end{array}$ & 0.715 & -0.010 & 0.766 & 0.631 & 0.738 & 0.750 & $\mathbf{0 . 7 9 3}$ \\
\hline
\end{tabular}

Appendix 5. Table 5. Cross Loading.

\begin{tabular}{|l|l|l|l|l|l|l|l|}
\hline & $\begin{array}{l}\text { Instructor } \\
\text { Information }\end{array}$ & $\begin{array}{l}\text { Service } \\
\text { Interaction }\end{array}$ & $\begin{array}{l}\text { Information } \\
\text { Quality }\end{array}$ & $\begin{array}{l}\text { System } \\
\text { Quality }\end{array}$ & $\begin{array}{l}\text { Perceived } \\
\text { Usefulness }\end{array}$ & CS & E-Loyalty \\
\hline II1 & $\mathbf{0 . 7 9 5}$ & 0.591 & 0.553 & 0.504 & 0.597 & 0.620 & -0.024 \\
\hline II2 & $\mathbf{0 . 7 9 4}$ & 0.618 & 0.637 & 0.544 & 0.559 & 0.621 & -0.018 \\
\hline II3 & $\mathbf{0 . 8 4 2}$ & 0.624 & 0.630 & 0.531 & 0.606 & 0.654 & -0.078 \\
\hline II4 & $\mathbf{0 . 8 5 0}$ & 0.629 & 0.653 & 0.521 & 0.652 & 0.640 & 0.005 \\
\hline II5 & $\mathbf{0 . 8 4 4}$ & 0.607 & 0.619 & 0.535 & 0.587 & 0.628 & -0.045 \\
\hline II6 & $\mathbf{0 . 7 8 9}$ & 0.556 & 0.544 & 0.468 & 0.491 & 0.538 & -0.026 \\
\hline SI1 & 0.678 & $\mathbf{0 . 8 3 9}$ & 0.762 & 0.670 & 0.684 & 0.704 & -0.013 \\
\hline SI2 & 0.537 & $\mathbf{0 . 8 2 6}$ & 0.632 & 0.607 & 0.632 & 0.647 & 0.043 \\
\hline SI3 & 0.612 & $\mathbf{0 . 7 8 3}$ & 0.572 & 0.563 & 0.597 & 0.575 & -0.006 \\
\hline SI4 & 0.550 & $\mathbf{0 . 7 7 2}$ & 0.616 & 0.593 & 0.621 & 0.558 & 0.021 \\
\hline SI5 & 0.577 & $\mathbf{0 . 8 2 0}$ & 0.638 & 0.579 & 0.683 & 0.675 & -0.049 \\
\hline SI6 & 0.568 & $\mathbf{0 . 8 0 2}$ & 0.618 & 0.604 & 0.639 & 0.639 & 0.001 \\
\hline
\end{tabular}



courses in hospitality programmes during Covid-19

\begin{tabular}{|c|c|c|c|c|c|c|c|}
\hline S17 & 0.677 & 0.858 & 0.755 & 0.654 & 0.723 & 0.715 & 0.022 \\
\hline IQ1 & 0.602 & 0.651 & 0.818 & 0.638 & 0.574 & 0.649 & -0.083 \\
\hline IQ2 & 0.703 & 0.679 & 0.870 & 0.674 & 0.624 & 0.648 & 0.006 \\
\hline IQ3 & 0.617 & 0.666 & 0.847 & 0.624 & 0.600 & 0.647 & -0.038 \\
\hline IQ4 & 0.608 & 0.704 & 0.847 & 0.654 & 0.632 & 0.671 & 0.003 \\
\hline IQ5 & 0.585 & 0.686 & 0.838 & 0.612 & 0.630 & 0.685 & -0.011 \\
\hline IQ6 & 0.629 & 0.689 & 0.857 & 0.663 & 0.611 & 0.621 & -0.044 \\
\hline IQ7 & 0.656 & 0.726 & 0.865 & 0.684 & 0.640 & \begin{tabular}{|l}
0.643 \\
\end{tabular} & -0.027 \\
\hline SY1 & 0.436 & 0.512 & 0.556 & 0.764 & 0.574 & 0.543 & 0.012 \\
\hline SY2 & 0.477 & 0.551 & 0.574 & 0.776 & 0.527 & 0.541 & 0.004 \\
\hline SY3 & 0.490 & 0.590 & 0.610 & 0.816 & 0.579 & 0.547 & 0.040 \\
\hline SY4 & 0.501 & 0.569 & 0.596 & 0.793 & 0.574 & 0.538 & -0.008 \\
\hline SY5 & 0.461 & 0.558 & 0.564 & 0.811 & 0.579 & 0.540 & -0.007 \\
\hline SY6 & 0.482 & 0.608 & 0.604 & 0.802 & 0.592 & 0.569 & -0.078 \\
\hline SY7 & 0.536 & 0.704 & 0.670 & 0.835 & 0.640 & 0.635 & -0.020 \\
\hline SY8 & 0.612 & 0.646 & 0.671 & 0.744 & 0.604 & 0.611 & -0.005 \\
\hline PU1 & 0.590 & 0.697 & 0.606 & 0.619 & 0.831 & 0.676 & 0.003 \\
\hline PU2 & 0.602 & 0.650 & 0.567 & 0.595 & 0.811 & 0.649 & -0.041 \\
\hline PU3 & 0.606 & 0.678 & 0.625 & 0.638 & 0.856 & 0.705 & 0.001 \\
\hline PU4 & 0.587 & 0.691 & 0.614 & 0.622 & 0.847 & 0.695 & 0.028 \\
\hline PU5 & 0.614 & 0.701 & 0.671 & 0.592 & 0.836 & 0.687 & 0.034 \\
\hline PU6 & 0.611 & 0.662 & 0.612 & 0.601 & 0.843 & 0.668 & 0.035 \\
\hline PU7 & 0.619 & 0.694 & 0.617 & 0.662 & 0.861 & 0.708 & 0.006 \\
\hline PU8 & 0.576 & 0.662 & 0.586 & 0.618 & 0.845 & 0.695 & 0.017 \\
\hline PU9 & 0.634 & 0.696 & 0.632 & 0.669 & 0.884 & 0.737 & 0.047 \\
\hline TFL1 & 0.622 & 0.648 & 0.600 & 0.567 & 0.698 & 0.856 & -0.015 \\
\hline TFL2 & 0.579 & 0.684 & 0.632 & 0.639 & 0.703 & 0.870 & -0.054 \\
\hline TFL3 & 0.663 & 0.705 & 0.686 & 0.634 & 0.710 & 0.885 & -0.059 \\
\hline TFL4 & 0.679 & 0.688 & 0.684 & 0.612 & 0.690 & 0.839 & -0.015 \\
\hline TFL5 & 0.715 & 0.704 & 0.713 & 0.635 & 0.727 & 0.867 & -0.011 \\
\hline SL1 & -0.029 & -0.005 & -0.051 & -0.007 & 0.003 & -0.034 & 0.908 \\
\hline SL2 & -0.049 & -0.002 & -0.023 & -0.012 & 0.013 & -0.034 & 0.929 \\
\hline SL3 & -0.032 & 0.011 & -0.023 & -0.010 & 0.029 & -0.035 & 0.909 \\
\hline SL4 & -0.001 & 0.009 & 0.007 & -0.007 & 0.018 & -0.009 & 0.741 \\
\hline
\end{tabular}

Appendix 6. Table 6. Path Coefficients.

\begin{tabular}{|l|c|c|c|c|c|}
\hline & Beta & $\begin{array}{c}\text { Standard } \\
\text { Deviation }\end{array}$ & $\begin{array}{c}\mathrm{T} \\
\text { Values }\end{array}$ & $\begin{array}{c}\mathrm{P} \\
\text { Values }\end{array}$ & Result \\
\hline $\begin{array}{l}\text { Instructor Information -> Perceived } \\
\text { Usefulness }\end{array}$ & 0.211 & 0.059 & 3.633 & 0.000 & Accepted \\
\hline Service Interaction -> Perceived Usefulness & 0.446 & 0.071 & 6.184 & 0.000 & Accepted \\
\hline Information Quality -> Perceived Usefulness & 0.013 & 0.076 & 0.062 & 0.951 & Rejected \\
\hline
\end{tabular}




\begin{tabular}{|l|c|c|c|c|c|}
\hline System Quality -> Perceived Usefulness & 0.260 & 0.079 & 3.394 & 0.001 & Accepted \\
\hline Perceived Usefulness -> Satisfaction & 0.818 & 0.026 & 31.833 & 0.000 & Accepted \\
\hline Satisfaction -> E-Loyalty & $\begin{array}{c}- \\
0.037\end{array}$ & 0.076 & 0.470 & 0.638 & Rejected \\
\hline
\end{tabular}

\section{Author Details}

Yoanita Alexandra is a Senior Lecturer in Hospitality at Universitas Multimedia Nusantara, Tangerang, Indonesia. Her present teaching and research interests are housekeeping management, food and beverage management, business entrepreneurship, and service marketing and e-commerce.

Septi Fahmi Choirisa is a Senior Lecturer at Universitas Multimedia Nusantara, Tangerang, Indonesia. She conducts research on Hospitality Management, Destination Marketing, Sustainable Destination, and Digital Transformation. 